\title{
Phenotypic and Genotypic Characterization of Bacteriocins in Enterococcal Isolates of Different Sources
}

\author{
Gamze Başbülbül Özdemir • Erman Oryaşın • \\ Hacı Halil Bıyık • Melihcan Özteber • \\ Bülent Bozdoğan
}

Received: 13 September 2010/Accepted: 23 December 2010/Published online: 3 February 2011

(C) Association of Microbiologists of India 2011

\begin{abstract}
A collection of 57 enterococcal isolates from different origin (including river, treatment plant, spring and garbage water, soil, animal, and vegetables from Aydin) was screened for the production of bacteriocins. Enterococci were identified at species levels as Enterococcus faecium (34), E. hirae (6), E. casseliflavus (4), E. durans (4), E. faecalis (4), E. mundtii (3) and E. avium (2). Of the 57 isolates 40 of them inhibited the growth of at least one indicator bacterium. Based on our PCR results 54 strains possesed enterocin genes. The genes of entA and entB were the most frequently detected structural genes among the PCR positive strains (54 and 53 strains, respectively) and the ent $B$ gene was always associated with ent $A$ gene. The highest combination of enterocin genes (24 of 54 strains) detected was entA, entB, entP and entL50A/B. The enterocins AS-48 and CylL $\mathrm{LSS}_{\mathrm{LS}}$ genes were not found. Three enterococcal isolates, 2 E. faecium and 1 E. hirae were not harbour any of tested enterocin genes. No correlation between the presence of enterocin structural genes and the origin of the strain was detected, also no relationship seemed to exist between the tested enterocin genes and the activity spectra of isolates. Genes encoding bacteriocins are widely disseminated among enterocci from different origin
\end{abstract}

Electronic supplementary material The online version of this article (doi:10.1007/s12088-011-0143-0) contains supplementary material, which is available to authorized users.

G. B. Özdemir $(\bowtie) \cdot H$. H. Bıyık · M. Özteber Faculty of Arts and Science, Department of Biology, Adnan Menderes University, 09100 Aydın, Turkey

e-mail: gbasbulbul@adu.edu.tr

E. Oryaşın · B. Bozdoğan

ADU BILTEM Epidemiology Unit, Adnan Menderes

University, 09100 Aydın, Turkey and more studies should be done for evaluate industrial potential of bacteriocins.

Keywords Bacteriocin - Enterococcus .

Enterocin Structural Genes · PCR

\section{Introduction}

Enterococci represent lactic-acid producing bacteria that can be isolated from different ecosystems such as human, animals, water, soil, plants, food/feed, waste and poultry [1]. Enterococci can produce antimicrobial peptides, called bacteriocins or more specifically enterocins with inhibitory activity against strains closely related to the producer microorganism [2]. It is assumed that bacteriocin production is a bacterial defense mechanism, which gives the producer strain a competitive advantage towards non-producer and bacteriocin sensitive strains in the same niche. In recent years, Franz et al., proposed simplified classification scheme for enterocins; Class I enterocins (lantibiotic enterocins), Class II enterocins (small, non-lantibiotic peptides); Class III enterocins (cyclic enterocins); and Class IV enterocins (large proteins) [3]. Cytolysin belongs to Class I enterocins, it is a two-peptide bacteriocin and both structural subunits contain lanthionie residues [4]. Class II can be subdivided into three subclasses: II.1, enterocin of the pediocin family (enterocin A, enterocin P and bacteriocin 31); II.2, enterocins synthesized without a leader peptide (enterocin L50A/B, and enterocin Q); II.3, other linear, non-pediocin-type enterocins (enterocin B). Class III enterocins includes cyclic antibacterial peptides like enterocin AS-48 and Class IV enterocins are large proteins such as enterolysin A [5]. A major portion of the bacteriocin-producing enterococci have been isolated from 
foods (cheese, meat, fish and vegetables), animals, and humans [6]. Bacteriocin producing enterococci have also been isolated from municipial wastes [7], sewage sludge [8], rumen content of different ruminants and animal wastes [9].

Many bacteriocins from enterococci have been purified and genetically characterized over the years, and most of them have been obtained from Enterococcus faecalis and Enterococcus faecium. Although a screening for production of bacteriocins by E. faecalis and E. faecium was the subject of several previous studies [10-14], only little information is available about this feature in E. avium, E. hirae, E. mundtii, E. casseliflavus and E. durans isolated from different environments. The aim of this study was to screen the production of antimicrobial activities as well as the presence of bacteriocin structural genes in enterococcal isolates include diverse species isolated from different sources in Turkey.

\section{Materials and Methods}

\section{Bacterial Strains}

A collection of 57 Enterococcus strains were isolated from different sources including water, soil, animal and vegetable samples. The Enterococci isolated by using $\mathrm{m}$-Enterococcus agar and species identification was based on $16 \mathrm{~S}$ rDNA sequence analysis. The frozen stocks were stored at $-80^{\circ} \mathrm{C}$ in skimed milk $(20 \% \mathrm{v} / \mathrm{v})$. The following cultures were tested for sensitivity to enterocins: Listeria sp. (food isolate), Listeria innocua DSM 20649, E.coli ATCC 35218, Enterococcus faecalis ATCC 51299,
Bacillus cereus ATCC 11778, Staphylococcus aureus ATCC 25923, Micrococcus luteus ATCC 9341.

\section{Bacteriocin Production Assay}

For detection of antimicrobial activity, $50 \mu \mathrm{l}$ of an overnight culture of the indicator strain was added to $5 \mathrm{ml}$ of molten soft BHI broth (Merck, Darmstadt, GERMANY) supplemented with $0.7 \%$ agar, mixed, and poured onto a BHI agar plate (Merck, Darmstadt, GERMANY). A single colony of each enterococci to be tested for antimicrobial activity was trasferred with a sterile toothpick to the agar plate seeded with the indicator bacteria [15]. Plates were incubated for $24 \mathrm{~h}$ at $37^{\circ} \mathrm{C}$ in aerobic conditions. The antimicrobial activity was visually detected by observing clear inhibition zones around the tested strain.

\section{PCR Detection of Enterocin Structural Genes}

Structural genes (cylL $L_{L S}$, entA, ent $B$, entP, entAS-48, entL50A/B and bac31) of different bacteriocins (Cytolysin $\mathrm{L}$, enterocin $\mathrm{A}$, enterocin $\mathrm{B}$, enterocin $\mathrm{P}$, enterocin AS-48, enterocin L50 A/B and bacteriocin 31 respectively) were studied by PCR in all isolated enterococci using primers included in Table 1. PCR was performed using Techne T-3000 thermocycler. All the PCR reactions were carried out in a final volume of $20 \mu \mathrm{l}$ containing $1 \times$ PCR buffer, $1.5 \mathrm{mM} \mathrm{MgCl} 2,200 \mathrm{mM}$ each of the four dNTPs, $0.5 \mathrm{mM}$ of each primer and 1.25 units of Taq DNA polymerase. The cycles used were $94^{\circ} \mathrm{C}$ for $5 \mathrm{~min}, 94^{\circ} \mathrm{C}$ for $30 \mathrm{~s}, 55^{\circ} \mathrm{C}$ (Ent $\mathrm{A}, \mathrm{B}$ and $\mathrm{P}$ ), $57^{\circ} \mathrm{C}$ (Bac 31 and $\mathrm{AS}-48$ ), $58^{\circ} \mathrm{C}$ (Cylls and Ent L50A/B) for $30 \mathrm{~s}$ and $72^{\circ} \mathrm{C}$ for $45 \mathrm{~s}$ for the next 35 cycles, $72^{\circ} \mathrm{C}$ for $5 \mathrm{~min}$ were used fort the last cycle.

Table 1 Specific primers used for PCR detection of enterocin structural genes

\begin{tabular}{|c|c|c|c|}
\hline Gene & Sequence $\left(5^{\prime}-3^{\prime}\right)$ & Fragment (bp) & References \\
\hline \multirow[t]{2}{*}{ entA } & F: GGTACCACTCATAGTGGAAA & 138 & [10] \\
\hline & R: CCCTGGAATTGCTCCACCTAA & & \\
\hline \multirow[t]{2}{*}{ ent $B$} & F: CAAAATGTAAAAGAATTAAGTACG & 201 & {$[10]$} \\
\hline & R: AGAGTATACATTTGCTAACCC & & \\
\hline \multirow[t]{2}{*}{ entP } & F: GCTACGCGTTCATATGGTAAT & 87 & {$[10]$} \\
\hline & R: TCCTGCAATATTCTCTTTAGC & & \\
\hline \multirow[t]{2}{*}{ ent $L 50 A / B$} & F: ATGGGAGCAATCGCAAAATTA & 274 & {$[10]$} \\
\hline & R: TAGCCATTTTTCAATTTGATC & & \\
\hline \multirow[t]{2}{*}{$A S-48$} & F: GAGGAGTATCATGGTTAAAGA & 339 & {$[10]$} \\
\hline & R: ATATTGTTAAATTACCAA & & \\
\hline \multirow[t]{2}{*}{ bact31 } & F: CCTACGTATTACGGAAATGGT & 130 & {$[10]$} \\
\hline & R: GCCATGTTGTACCCAACCATT & & \\
\hline \multirow[t]{2}{*}{$c y l L_{L S}$} & F: GGCGGTATTTTTACTGGAGT & 248 & {$[4]$} \\
\hline & R: CCTACTCCTAAGCCTATGGTA & & \\
\hline
\end{tabular}


Table 2 Sources, harboured enterocin genes and inhibitory spectrum of enterococcal isolates

\begin{tabular}{|c|c|c|c|c|c|c|c|}
\hline \multirow[t]{2}{*}{ Isolate } & \multirow[t]{2}{*}{ Source } & \multirow[t]{2}{*}{ Enterocin genes } & \multicolumn{5}{|l|}{ Inhibition } \\
\hline & & & Listeria sp. & L. inпосиа & E. faecalis & B. cereus & S. aureus \\
\hline E. faecium HBE-1 & River water & $\mathrm{A}, \mathrm{B}, \mathrm{bac} 31, \mathrm{~L} 50 \mathrm{~A} / \mathrm{B}$ & + & + & + & - & - \\
\hline E. faecium $\mathrm{HBE}-2$ & River water & $\mathrm{A}, \mathrm{B}, \mathrm{L} 50 \mathrm{~A} / \mathrm{B}$ & + & + & + & - & - \\
\hline E. faecium $\mathrm{HBE}-3$ & River water & $\mathrm{A}, \mathrm{B}, \mathrm{L} 50 \mathrm{~A} / \mathrm{B}$ & +++ & +++ & ++ & - & - \\
\hline E. casseliflavus $\mathrm{HBE}-4$ & River water & $\mathrm{A}, \mathrm{B}, \mathrm{L} 50 \mathrm{~A} / \mathrm{B}$ & - & + & - & - & + \\
\hline E. faecium HBE-5 & River water & A, B & - & - & - & - & - \\
\hline E. casseliflavus HBE-6 & River water & A, B & + & + & - & + & + \\
\hline E. faecium HBE-7 & River water & $\mathrm{A}, \mathrm{B}, \mathrm{P}$ & +++ & +++ & ++ & - & + \\
\hline E. faecium $\mathrm{HBE}-8$ & River water & $\mathrm{A}, \mathrm{B}, \mathrm{P}, \mathrm{L} 50 \mathrm{~A} / \mathrm{B}$ & +++ & +++ & ++ & - & + \\
\hline E. faecium HBE-9 & River water & $\mathrm{A}, \mathrm{B}, \mathrm{P}$ & +++ & +++ & ++ & - & + \\
\hline E. hirae $\mathrm{HBE}-10$ & Agricultural soil & - & - & - & - & - & - \\
\hline E. hirae HBE-11 & Agricultural soil & $\mathrm{A}, \mathrm{B}$ & - & - & - & - & - \\
\hline E. durans HBE-12 & Agricultural soil & $\mathrm{A}, \mathrm{B}$ & +++ & +++ & ++ & - & + \\
\hline E. faecium HBE-13 & Agricultural soil & $\mathrm{A}, \mathrm{B}$ & - & - & - & - & + \\
\hline E. faecium HBE-14 & Treatment plant water & $\mathrm{A}, \mathrm{B}, \mathrm{P}$ & - & - & - & - & - \\
\hline E. faecalis HBE-15 & Treatment plant water & $\mathrm{A}, \mathrm{B}, \mathrm{P}$ & - & - & - & - & - \\
\hline E. faecalis HBE-16 & Treatment plant water & $\mathrm{A}, \mathrm{B}, \mathrm{P}, \mathrm{L} 50 \mathrm{~A} / \mathrm{B}$ & - & - & - & - & - \\
\hline E. faecium HBE-17 & Treatment plant water & $\mathrm{A}, \mathrm{B}, \mathrm{P}, \mathrm{L} 50 \mathrm{~A} / \mathrm{B}$ & +++ & +++ & ++ & - & + \\
\hline E. faecium HBE-18 & Treatment plant water & $\mathrm{A}, \mathrm{B}, \mathrm{P}$ & - & - & - & - & + \\
\hline E. faecium HBE-19 & Treatment plant water & - & - & - & - & - & + \\
\hline E. faecium HBE-20 & Treatment plant water & $\mathrm{A}, \mathrm{B}, \mathrm{P}$ & - & - & - & - & + \\
\hline E. faecium HBE-21 & Treatment plant water & $\mathrm{A}, \mathrm{B}, \mathrm{P}$ & - & - & - & - & + \\
\hline E. faecalis $\mathrm{HBE}-22$ & Treatment plant water & $\mathrm{A}, \mathrm{B}, \mathrm{P}$ & - & - & - & - & - \\
\hline E. faecium HBE-23 & Treatment plant water & $\mathrm{A}, \mathrm{B}, \mathrm{P}$ & ++ & ++ & ++ & - & + \\
\hline E. faecium HBE-24 & Treatment plant water & $\mathrm{A}, \mathrm{B}, \mathrm{P}$ & ++ & ++ & ++ & - & + \\
\hline E. faecium HBE-25 & Treatment plant water & $\mathrm{A}, \mathrm{B}, \mathrm{P}$ & - & - & - & - & - \\
\hline E. faecium HBE-26 & Sheep rectum & $\mathrm{A}, \mathrm{B}, \mathrm{P}$ & + & - & - & + & + \\
\hline E. faecium HBE-27 & Sheep rectum & $\mathrm{A}, \mathrm{B}, \mathrm{P}$ & - & - & - & + & + \\
\hline E. hirae $\mathrm{HBE}-28$ & Sheep caecum & $\mathrm{A}, \mathrm{B}, \mathrm{P}$ & - & - & - & - & - \\
\hline E. hirae HBE-29 & Sheep caecum & $\mathrm{A}, \mathrm{B}, \mathrm{P}, \mathrm{L} 50 \mathrm{~A} / \mathrm{B}$ & - & - & - & - & - \\
\hline E. faecium HBE-30 & Sheep caecum & $\mathrm{A}, \mathrm{B}, \mathrm{P}, \mathrm{L} 50 \mathrm{~A} / \mathrm{B}$ & - & - & - & - & + \\
\hline E. faecium HBE-31 & Cattle rectum & $\mathrm{A}, \mathrm{B}, \mathrm{L} 50 \mathrm{~A} / \mathrm{B}$ & ++ & ++ & + & - & + \\
\hline E. faecium $\mathrm{HBE}-32$ & Cattle rectum & $\mathrm{A}, \mathrm{B}, \mathrm{L} 50 \mathrm{~A} / \mathrm{B}$ & ++ & ++ & + & & + \\
\hline E. faecium HBE-33 & Cattle rectum & A, B & - & - & - & - & + \\
\hline E. faecium HBE-34 & Cattle caecum & $\mathrm{A}, \mathrm{B}, \mathrm{L} 50 \mathrm{~A} / \mathrm{B}$ & - & - & - & - & + \\
\hline E. faecium HBE-35 & Cattle caecum & $\mathrm{A}, \mathrm{B}, \mathrm{P}, \mathrm{L} 50 \mathrm{~A} / \mathrm{B}$ & +++ & +++ & ++ & - & + \\
\hline E. faecium HBE-36 & Cattle caecum & - & - & - & - & - & + \\
\hline E. faecalis $\mathrm{HBE}-37$ & Spring water & $\mathrm{A}, \mathrm{B}, \mathrm{P}, \mathrm{L} 50 \mathrm{~A} / \mathrm{B}$ & - & - & - & - & - \\
\hline E. avium $\mathrm{HBE}-38$ & Spring water & $\mathrm{A}, \mathrm{B}, \mathrm{P}, \mathrm{L} 50 \mathrm{~A} / \mathrm{B}$ & - & - & - & - & + \\
\hline E. avium HBE-39 & Spring water & $\mathrm{A}, \mathrm{B}, \mathrm{P}, \mathrm{L} 50 \mathrm{~A} / \mathrm{B}$ & - & - & - & - & - \\
\hline E. casseliflavus HBE-40 & Spring water & $\mathrm{A}, \mathrm{B}, \mathrm{P}, \mathrm{L} 50 \mathrm{~A} / \mathrm{B}$ & - & - & - & + & + \\
\hline E. casseliflavus HBE-41 & Spring water & $\mathrm{A}, \mathrm{B}, \mathrm{P}, \mathrm{L} 50 \mathrm{~A} / \mathrm{B}$ & - & + & - & - & + \\
\hline E. mundtii HBE-42 & Spring water & $\mathrm{A}, \mathrm{B}, \mathrm{P}, \mathrm{L} 50 \mathrm{~A} / \mathrm{B}$ & - & + & - & - & - \\
\hline E. faecium HBE-43 & Spring water & $\mathrm{A}, \mathrm{P}, \mathrm{L} 50 \mathrm{~A} / \mathrm{B}$ & - & - & - & - & + \\
\hline E. faecium HBE-44 & Spring water & $\mathrm{A}, \mathrm{B}, \mathrm{P}, \mathrm{L} 50 \mathrm{~A} / \mathrm{B}$ & - & - & - & - & + \\
\hline E. hirae $\mathrm{HBE}-45$ & Spring water & $\mathrm{A}, \mathrm{B}, \mathrm{P}, \mathrm{L} 50 \mathrm{~A} / \mathrm{B}$ & - & - & - & - & - \\
\hline E. durans HBE-46 & Spring water & $\mathrm{A}, \mathrm{B}, \mathrm{P}, \mathrm{L} 50 \mathrm{~A} / \mathrm{B}$ & + & + & - & - & - \\
\hline E. durans HBE-47 & Spring water & $\mathrm{A}, \mathrm{B}, \mathrm{L} 50 \mathrm{~A} / \mathrm{B}$ & - & - & - & - & - \\
\hline
\end{tabular}


Table 2 continued

\begin{tabular}{|c|c|c|c|c|c|c|c|}
\hline \multirow[t]{2}{*}{ Isolate } & \multirow[t]{2}{*}{ Source } & \multirow[t]{2}{*}{ Enterocin genes } & \multicolumn{5}{|l|}{ Inhibition } \\
\hline & & & Listeria sp. & L. iпnосиа & E. faecalis & B. cereus & S. aureus \\
\hline E. faecium HBE-48 & Garbage water & $\mathrm{A}, \mathrm{B}, \mathrm{P}, \mathrm{L} 50 \mathrm{~A} / \mathrm{B}$ & +++ & +++ & ++ & - & - \\
\hline E. faecium HBE-49 & Garbage water & $\mathrm{A}, \mathrm{B}, \mathrm{P}, \mathrm{L} 50 \mathrm{~A} / \mathrm{B}$ & +++ & +++ & ++ & - & + \\
\hline E. durans HBE-50 & Garbage water & $\mathrm{A}, \mathrm{B}, \mathrm{P}, \mathrm{L} 50 \mathrm{~A} / \mathrm{B}$ & + & + & + & - & + \\
\hline E. mundtii HBE-51 & Vegetable & $\mathrm{A}, \mathrm{B}, \mathrm{P}, \mathrm{L} 50 \mathrm{~A} / \mathrm{B}$ & ++ & ++ & + & + & - \\
\hline E. hirae $\mathrm{HBE}-52$ & Vegetable & $\mathrm{A}, \mathrm{B}, \mathrm{L} 50 \mathrm{~A} / \mathrm{B}$ & - & - & - & - & - \\
\hline E. mundtii HBE-53 & Vegetable & $\mathrm{A}, \mathrm{B}, \mathrm{P}, \mathrm{L} 50 \mathrm{~A} / \mathrm{B}$ & - & - & - & - & - \\
\hline E. faecium HBE-54 & Vegetable & $\mathrm{A}, \mathrm{B}, \mathrm{P}, \mathrm{L} 50 \mathrm{~A} / \mathrm{B}$ & +++ & +++ & ++ & - & + \\
\hline E. faecium HBE-55 & Vegetable & $\mathrm{A}, \mathrm{B}, \mathrm{P}, \mathrm{L} 50 \mathrm{~A} / \mathrm{B}$ & +++ & +++ & ++ & - & + \\
\hline E. faecium HBE-56 & Vegetable & $\mathrm{A}, \mathrm{B}, \mathrm{P}, \mathrm{L} 50 \mathrm{~A} / \mathrm{B}$ & +++ & +++ & ++ & - & - \\
\hline E. faecium HBE-57 & Vegetable & $\mathrm{A}, \mathrm{B}, \mathrm{P}, \mathrm{L} 50 \mathrm{~A} / \mathrm{B}$ & - & - & - & - & - \\
\hline
\end{tabular}

+ weak inhibition, ++ moderate inhibition, +++ strong inhibition

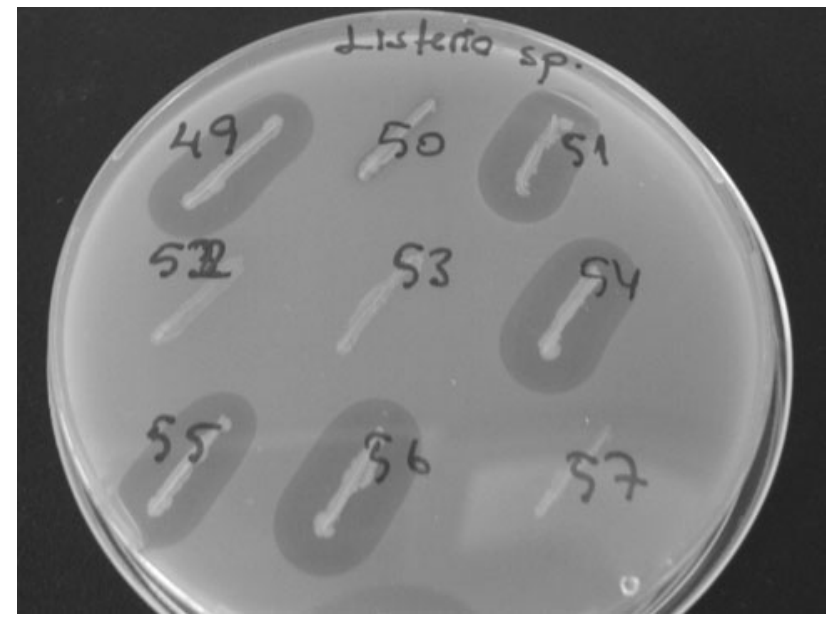

Fig. 1 Examples of enterococcal isolates and their inhibition zones against Listeria $\mathrm{sp}$

Positive and negative controls were included in all assays, except for entAS-48 and $C y l L_{\mathrm{LS}}$.

\section{Results and Discussion}

The Enterococci used in this study were isolated from different water, soil, animal and vegetable samples in Aydın (Turkey). Based on 16S rDNA sequence analysis strains were identified as E. faecium (34), E. hirae (6), E. faecalis (4), E. casseliflavus (4), E. durans (4), E. mundtii (3), E. avium (2). Strains were collected from the following sources river water $(n=9)$, soil $(n=4)$, treatment water plant $(n=12)$, sheep and cattle rectums and caecums $(n=11)$, spring water $(n=11)$, garbage water $(n=3)$, vegetable $(n=7)$ (Table 2$)$.
The 57 enterococcal isolates were screened for antibacterial activity since they may be produce enterocins to control the growth of the tested indicator bacteria (Fig. 1). Table 2 shows the profile of the inhibitory effects exhibited by the enterococcal strains, as well as the specific bacteriocin genes harboured by them.

Of the 57 isolates screened, 40 of them $(70.2 \%)$ were found to be effective against at least one of the indicator bacteria. The isolates having antilisterial activity included 18 E. faecium, 3 E. casseliflavus, 3 E. durans and 2 E. mundtii. Of the 40 isolates with antibacterial activity, 12 of them were found to be inhibitory only against to $S$. aureus (11 E. faecium and $1 \mathrm{E}$. avium). The similar results were reported in previous studies that most enterocin producing enterococci displayed antilisterial activity, while a fewer portion of them also showed antibacterial spectrum activity against Staphylococcus spp., Bacillus spp. and Clostridium spp [3, 10, 16-18]. No correlation was found between the origin of the strains and the inhibitory spectrum.

According to our PCR results occurence of enterocin structural genes seems to be widespread among enterococcal strains isolated from different sources and high frequency of the occurence of enterocin structural genes (94.7\%) was observed (Fig. 2). It was reported that, in a collection of 61 enterococci isolated from environmental sources like surface and waste waters, sheep manure, enterocin structural gene positive strains were found to be $57.4 \%$ [22]. In another research, 64 of 122 (52.5\%), inhibitory Enterococcus strains isolated from food and feed, animal, clinical and non-clinical samples, were found to harbour at least one enterocin structural gene [10]. None of the bacteriocin genes tested in this study were demonstrated in two strains of E. faecium (HBE-19, HBE-36) and E. hirae HBE-10, which showed antibacterial activity 

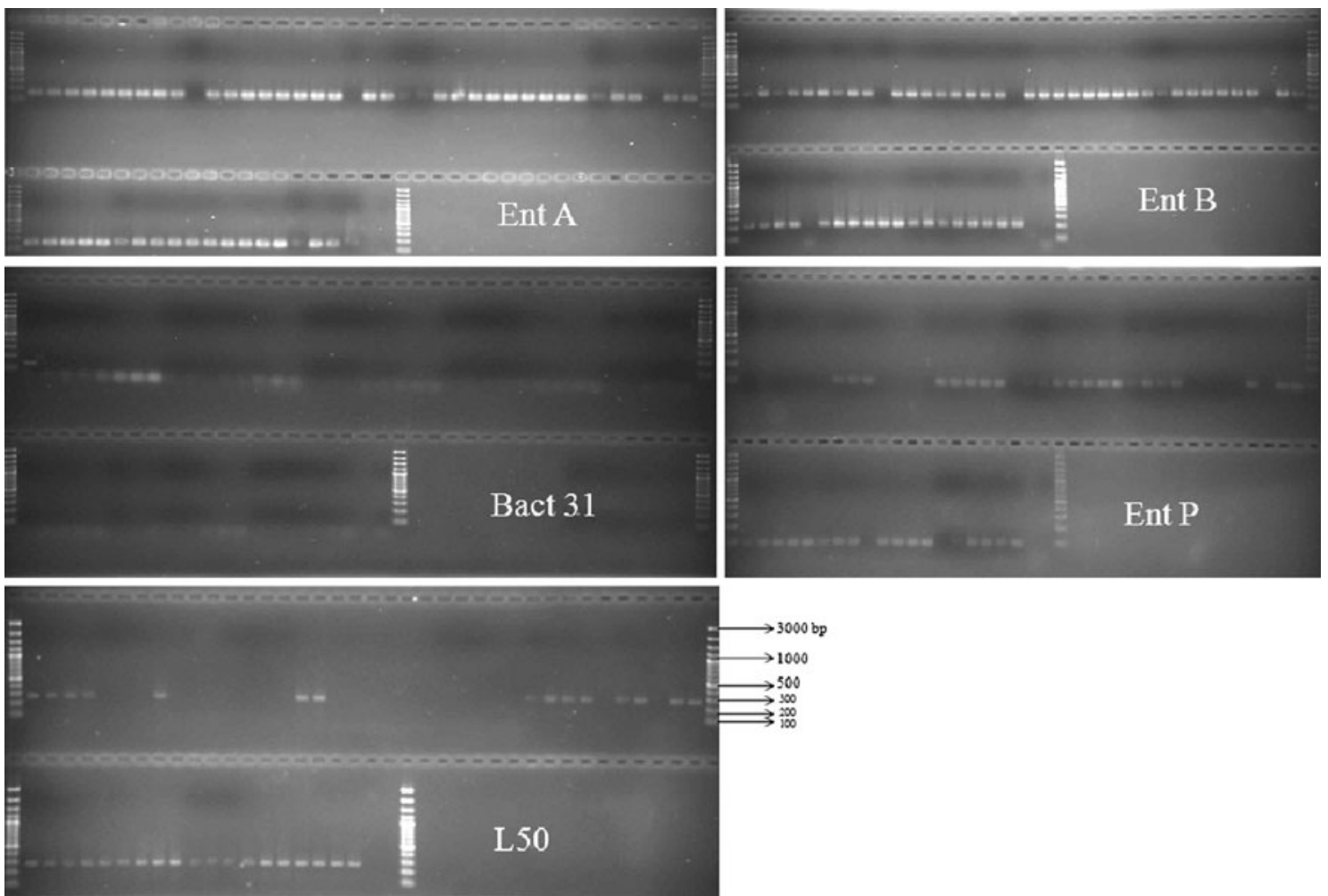

Fig. 2 Amplification gel pictures of the enterocin structural genes of enteroccal isolates. Lanes 1,40, 41 and 63 are 100 bp-DNA ladder. Lanes after ladder are isolate numbers in order of HBE1-HBE57, last lane before ladder is negative control

against $S$. aureus. Genes encoding new bacteriocins or other non-tested known bacteriocins could be included in those isolates. Although the detection of enterocin structural genes must not necessiraly correspond with the production of the bacteriocin, it can be speculated that various environments require various level of bacterial defense mechanism thus also the presence of bacteriocin genes as the basis for bacteriocin production [14].

Bacteriocin production seemed to be correlated to the species involved in this study; all E. hirae (6) and E. faecalis (4) were non-producers. The other strains had no activity against none of the indicator bacteria were $E$. faecium (4), E. mundtii (1), E. avium (1) and E. durans (1). All of these non-producer isolates except for $E$. hirae HBE10 , had various combination of enterocin genes. The detection of enterocin structural gene does not means the production of the corresponding enterocin [14] and existence of silent bacteriocin genes hes been previously reported in other studies $[2,19,20]$. It emphasized by Nes et al., [21] identification of putative bacteriocin genes does not necessarily mean that the relevant bacterium produces antimicrobial activity and a lack of detectable antimicrobial activity does not necessarily mean that genes involved in bacteriocin production are defective. First, because of some peptide bacteriocins act only a narrow range of target bacteria, it is of key importance to use a susceptible indicator. Secondly, the production of peptide bacteriocins is often regulated. Deficiency in production of antimicrobial activity is often due to a dysfunctional genetic system.

The structural genes of Enterocins A and B were shown to be most frequent genes (100 and 98.1\%) among PCR positive strains, respectively in this study. Enterocin B gene was always found to be together with enterocin A gene. Similar to our results the enterocin B structural gene was always associated with the presence of enterocin B gene in previous studies due to the fact that no transport genes have been found for enterocin B producers [10, 23].

Enterocin P and Enterocin L50 A/B were found to be 72.2 and $62.9 \%$, respectively. Enterocins $\mathrm{A}$ and $\mathrm{P}$ are belong to pediocin family and they are grouped in Class II.1 bacteriocins, which are very effective for growth of listeriae [24]. Enterocin B classified in the subgroup II.3, non-pediocin type enterocins. The individual peptides enterocin L50A and enterocin L50B possesed antimicrobial activity, with the L50A peptide being most active and enterocin L50 is grouped in Class II.c, leaderless type.

The combination of two different genes was observed in 6 strains $\left(11.1 \%\right.$ of $\mathrm{PCR}^{+}$strains). Three different genes were detected in 21 strains $(38.9 \%)$ and four different genes were present in 25 strains $(46.3 \%)$. The wide enterocin genes distribution may be due to remarkable ability 
of enterococci to disseminate and receive genetic material between strains but also between genera [14].

Cytolysin and enterocin AS-48 genes were not found any of examined enterococci. Cytolysin is the only twopeptide lantibiotic isolated from enterococci with cytolytic (hemolytic) activity. Cytolysin is a virulence factor and consequently it is not considered useful as an antimicrobial agent [22]. The structural gene of bacteriocin AS-48 has been examined in enterococcal isolates and bacteriocins that very closely related or identical to peptide AS-48 were detected in E. faecalis and E. faecium isolates [25].

In conclusion, $70.2 \%$ of the enterococcal isolates included in this study showed antimicrobial activity against at least one of indicator bacteria and $94.7 \%$ of isolates harboured various enterocin structural genes. Enterocin structural genes are widely distributed and they can be found in possible combinations together. The presence of four enterocin genes in 25 strains in this study indicates the high genetic potential of many strains to produce various enterocins. Because of these properties screening of enterocin genes may offer great possibilities for isolation of bacteriocin producing strains and their use in the food industry.

\section{References}

1. Devriese LA, Hommez J, Wijfels R, Haesebrouck F (1991) Composition of the Enterococcal and Streptococcal intestinal flora of poultry. J Appl Bacteriol 71:46-50

2. Poeta P, Igrejas G, Costa D, Sargo R, Rodrigues J, Torres C (2008) Virulence factors and bacteriocins in faecal enterococci of wild boars. J Basic Microbiol 48:385-392

3. Franz CM, Van Belkum MJ, Holzapfel WH, Abriouel H, Galvez A (2007) Diversity of enterococcal bacteriocins and their grouping in a new classification scheme. FEMS Microbiol Rev 31:293-310

4. Booth MC, Bogie CP, Sahl HG, Siezen RL, Hatter KL, Gilmore MS (1996) Structural analysis and proteolytic activation of Enterococcus faecalis cytolysin, a novel lantibiotic. Mol Microbiol 21:1175-1184

5. Nilsen T, Nes IF, Holo H (2003) Enterolysin A, a cell wall degrading bacteriocin from Enterococcus faecalis LMG 2333. Appl Environ Microbiol 69:2975-2984

6. Foulquie Moreno MR, Sarantinopoulos P, Tsakalidou E, DeVuyst L (2006) The role and application of enterococci in food and health. Int J Food Microbiol 106:1-24

7. Lauková A, Jurin P (1997) Distribution and characterization of Enterococcus species in municipal sewages. Microbios 97:73-80

8. Marekova M, Laukova A, Skaugen M, Nes I (2007) Isolation and characterization of a new bacteriocin, termed enterocin $\mathrm{M}$, produced by environmental isolate Enterococcus faecium AL41. J Ind Microbiol Biotechnol 34:533-537

9. Laukova A, Marekova M (2001) Production of bacteriocins by different Enterococcal isolates. Folia Microbiol 46:49-52

10. De Vuyst L, Foulquie Moreno MR, Revets H (2003) Screening for enterocins and detection of hemolysin and vancomycin resistance in enterococci of different origins. Int J Food Microbiol $84: 299-318$

11. Klibi N, Jouini A, Rojo-Bezares B, Masmoudi A, Ruiz-Larrea F, Boudabous A, Torres C (2008) Phenotypic and genotypic characterization of bacteriocins in clinical enterococcal isolates of Tunisia. World J Microbiol Biotechnol 24:653-657

12. Sabia C, Niederhausern S, Guerrieri E, Messi P, Anacarso I, Monicardi G, Bondi M (2008) Detection of bacteriocin production and virulence traits in vancomycin-resistant enterococci of different sources. J Appl Microbiol 104:970-979

13. Strompfova V, Laukova A (2007) In vitro study on bacteriocin production of Enterococci associated with chickens. Anaerobe $13: 228-237$

14. Strompfova V, Laukova A, Simonova M, Marcinakova M (2008) Occurence of the structural enterocin A, P, B, L50B genes in enterococci of different origin. Vet Microbiol 132:293-301

15. Del Campo R, Tenorio C, Jimenez-Diaz R, Rubio C, Gomez-Lus R, Baquero F, Torres C (2001) Bacteriocin production in vancomycinresistant and vancomycin-susceptible Enterococcus isolates of different origins. Antimicrob Agents Chemother 45:905-912

16. Cleveland J, Montville TJ, Nes IF, Chikindas ML (2001) Bacteriocins: safe, natural antimicrobials for food preservation. Int $\mathrm{J}$ Food Microbiol 71:1-20

17. Deegan LH, Cotter PD, Hill C, Ross P (2006) Bacteriocins: biological tools for bio-preservation and shelf-life etension. Int Dairy J 16:1058-1071

18. Giraffa G (1995) Enterococcal bacteriocins: their potential as antilisteria factors in dairy technology. Food Microbiol 12:291-299

19. Eaton TJ, Gasson MJ (2001) Molecular screening of Enterococcus virulence determinants and potential for genetic exchange between food and medical isolates. Appl Environ Microbiol 67:1628-1635

20. Semedo T, Santos MA, Lopes MF, Figueiredo Marques JJ, Barreto Crespo MT, Tenreiro R (2003) Virulence factors in food, clinical and reference enterococci: a common trait in the genus? Syst Appl Microbiol 26:13-22

21. Nes IF, Diep DB, Holo H (2007) Bacteriocin diversity in Streptococcus and Enterococcus. J Bacteriol 189:1189-1198

22. Pangallo D, Harichova J, Karelova E, Drahovska H, Chovanova K, Feriane P, Turna J, Timko J (2004) Molecular investigation of enterococci isolated from different environmental sources. Biologia 59:829-837

23. Franz CM, Worobo RW, Quadri LEN, Schillinger U, Holzapfel WH, Vederas JC, Stiles ME (1999) Atypical genetic locus associated with constitutive production of enterocin B by Enterococcus faecium BFE 900. Appl Environ Microbiol 65:2170-2178

24. Eijsink VG, Skeie M, Middelhoven PH, Brurberg MB, Nes IF (1998) Comparative studies of class IIa bacteriocins of lactic acid bacteria. Appl Environ Microbiol 64:3275-3281

25. Joosten HMLJ, Rodriguez E, Nunez M (1997) PCR detection of sequences similar to the AS-48 structural gene in bacteriocin producing enterococci. Lett Appl Microbiol 24:40-42 